\title{
Induction Somaclonal Variation in Pear Plants (Pyrus Communis var. Betulifolia) for Salinaty Tolerance Through Tissue Culture Technique.
}

\author{
A. O. Rayan and Nahla A. Awad \\ Fruit and Ornmental Breeding Department, Horticulture \\ Research Institute, Agricultural Research Centre, Cairo, Egypt.
}

\begin{abstract}
ALINITY is one of the major environmental stresses that challenge plant growth and crop productivity worldwide. In the present investigation, an attempt to introduce tolerant pear rootstock was achieved. Callus of betulifolia were subjected to different concentration of sodium chloride as a source of salinity (1000 mg.L-1, $2000 \mathrm{mg} . \mathrm{L}^{-1}, 3000 \mathrm{mg} . \mathrm{L}^{-1}, 4000 \mathrm{mg} . \mathrm{L}^{-1}$ and $5000 \mathrm{mg} \cdot \mathrm{L}^{-1}$ ) via in vitro culture technique. Survival calluses decreased in all of the tested concentrations, however, no survival calluses were obtained at 5000 $\mathrm{mg} . \mathrm{L}^{-1}$. Moreover, regenerated plants were also decreased with the increasing of salt concentration. On morphological level, the 1000 mg. $\mathrm{L}^{-1}$ concentration revealed high measurement in compare to the control. The opposite was true for the $2000 \mathrm{mg} . \mathrm{L}^{-1}, 3000 \mathrm{mg} . \mathrm{L}^{-1}$ and $4000 \mathrm{mg} \cdot \mathrm{L}^{-1}$. Increment of salt concentration reduced both of the fresh weight and relative growth of fresh weight gradually from the 1000 $\mathrm{mg} . \mathrm{L}^{-1}$ to $4000 \mathrm{mg} . \mathrm{L}^{-1}$. Chemically, proline, sodium and chloride content were gradually increased with the increasing of sodium chloride concentrations. Meanwhile, salinity stress recorded drastic effect on chlorophyll content especially at $4000 \mathrm{mg} . \mathrm{L}^{-1}$, total chlorophyll content were decreased by the increasing of salt concentration. It could be recommended to examine the resistant plants with higher concentrations of salinity and grafted these plants by different cultivars of pear.
\end{abstract}

Pear (Pyrus communis) is the third most important temperate fruit species after grape and apple (Chevreau et al.,1997). The genus Pyrus belongs to the subfamily Maloideae of the Rosaceae. Over the years, plant breeders have developed very productive cultivars of high quality, resistant to diseases and adapted to the demands of the market and of industry (Grandillo et al., 1999).

Salinity affects almost every aspect of the physiology and biochemistry of plants and significantly reduces yield (Cuartero et al., 2006). As saline soils and saline waters are common around the world (Sengupta and Majumder, 2009), and becoming a serious agricultural problem, especially in irrigated lands located in semiarid zones, where $20-30 \%$ of the land is seriously damaged by salt (FAO, 2002). Moreover, salinity is one of the major environmental stresses that challenge plant growth and crop productivity world wide (Sen and Mohammed, 1994). Producing sustainable and profitable crops under these conditions needs technological and biological approaches, including selection of 
new, more salt tolerant cultivars of named plants using conventional breeding programs or tissue culture techniques (Al Mansoori et al., 2007). Great effort has been devoted to understanding physiological aspects of tolerance to salinity in plants, as a basis for plant breeders to develop salinity-tolerant genotypes. In spite of this great effort, only a small number of cultivars, partially tolerant to salinity, have been developed. Further effort is necessary if the exploitation of saline soils and saline waters that are not currently usable is to be achieved.

Conventional breeding by hybridization is often inefficient towards salinity tolerance because of difficulty using the pre-existing variability i.e., quantitative nature of resistance, high degree of heterozygosity etc. (Yacoubi et al., 2010). The success achieved by past attempts to generate salt-tolerant genotypes, both through in vitro culture selection and conventional breeding programmes, (Flowers, 2004) have fuelled hopes that the problems might be solved. Tissue culture is a useful method for increasing the stress tolerance of plants chiefly because of totpotency, which refers to the fact that most plant cells contain a complete genome of the species and thus are at least potentially capable of becoming entire plants. Providing that individual cells can be convinced to produce entire plants or at lest shoots, large population of cell can be maintained and in many cases selected to obtain agriculturally useful mutant (Chandler et al., 1987 and Abd El-Rahman et al., 2007).

New cultivars bred for salt tolerance has not only to be salt tolerant, but also achieve the same attributes of productivity and quality seen in modern cultivars. Thus, in vitro culture techniques introduce an alternative method to select cell lines tolerant to salinity.

The aim of this study is to develop in vitro, salt tolerant cells of pear rootstock namely, Pyrus communis var. betulifolia.

\section{Material and Methods}

The investigations of the present study was achieved at the tissue culture and Germplasm Conservation Research lab. of the Horticulture Research Institute Giza during 2011 and 2012 seasons.

\section{Plant Material}

Selected meristem tips form Pyrus communis var. betulifolia seedlings were sterilized by $70 \%$ ethanol for $10 \mathrm{~min}$. followed by sterilization with $15 \%$ sodium hypochlorite for $15 \mathrm{~min}$. and finally rinsed in sterile distilled water 3 times.

\section{Culture Medium}

Explants were dissected into small pieces $(0.3 \mathrm{~cm})$ and cultured on Murashige and Skoog media (1962) supplemented with $2.8 \mathrm{mg} / \mathrm{l}$ May-inositol $+2.5 \mathrm{mg} / \mathrm{l}$ thiamine $\mathrm{Hcl}+1 \mathrm{mg} / \mathrm{l}(\mathrm{BAP})$. After six weeks, formed calluses were transfer into the same media which supplemented mg. $\mathrm{L}^{-1}$ with different concentrations of $\mathrm{NaCl}$ for Salinity $\left(0.00,1000 \mathrm{mg} . \mathrm{L}^{1}, 2000 \mathrm{mg} . \mathrm{L}^{-1}, 3000 \mathrm{mg} . \mathrm{L}^{-1}, 4000 \mathrm{mg} . \mathrm{L}^{-1}\right.$ and $\left.5000 \mathrm{mg} . \mathrm{L}^{-1}\right)$ and kept in this media for three weeks. Calluses were enhanced for regeneration after Egypt. J. Hort. Vol. 40, No.1 (2013) 
two weeks of salinity treatment, shoots were generated after 30 days using full strength of MS media supplemented with $2.8 \mathrm{mg} / \mathrm{L}$ May-Inositol $+2.5 \mathrm{mg} / \mathrm{L}$ thiamine $\mathrm{Hcl}+1 \mathrm{mg} / \mathrm{L}(\mathrm{BAP})+30 \mathrm{gm} / \mathrm{L}$ sucrose $+7 \mathrm{gm} / \mathrm{L}$ agar and adjusted to $\mathrm{PH}$ 5.6. Regenerated shoots were cultured on multiplication medium (full strength MS media+ 2.8mg/L May-Inositol $+2.5 \mathrm{mg} / \mathrm{L}$ thiamine $\mathrm{HCl}+2 \mathrm{mg} / \mathrm{L}(\mathrm{BAP})+30 \mathrm{gm} / \mathrm{L}$ sucrose $+7 \mathrm{gm}$ agar/L and adjusted to $\mathrm{PH} 5.6$ )

Multipled shoots were separated into individual shoot and transferred onto rooting medium (half strength MS media+ $2.8 \mathrm{mg} / \mathrm{L}$ May-Inositol $+2.5 \mathrm{mg} / \mathrm{L}$ thiamine $\mathrm{Hcl}+0.5 \mathrm{mg} / \mathrm{L}(\mathrm{IBA})+20 \mathrm{gm} / \mathrm{L}$ sucrose $+7 \mathrm{gm}$ agar/L and adjusted to $\mathrm{PH}$ 5.6) for another 4 weeks.

For acclimization, the plants were transplanted into small plastic pots containing of peatmoos and sand 2:1 (v/v) in greenhouse.

\section{The following data were recorded} Vegetative growth/Plant

- Number of callus survival, number of regenerated plants, number of survival, plants, shoot length $(\mathrm{cm})$, number of leaves, leave length $(\mathrm{cm})$, leave area $(\mathrm{cm})$, root length $(\mathrm{cm})$, number of roots and number of acclimized plants.

- Fresh weight of regenerated plantlets were measured and expressed as growth rate $(\mathrm{GR})$, relative to initial weight $(\mathrm{GR}=$ (final weight - initial weight $)$ / initial weight) and as relative growth rate (RGR), relative to GR of control [RGR = $100 \times$ GR stress /GR control] according to Yacoubi et al.(2010).

\section{Chemical analysis}

Sodium determination: Sample of $0.2 \mathrm{gm}$ was grounded and digested using the procedure suggested by Jackson (1958). The digested solution was then used for sodium determination by flame photometer according to method recommended by Brown and Lilleland (1946).

- Chloride determination: A dry sample (0.2) extracted under hot water then titrated with silver nitrate as mentioned by Higinbothan et al. (1967).

Total chlorophyll: Total chlorophyll was determined using chlorophyll meter (Model SPAD-502). Total chlorophyll was estimated as $\mu \mathrm{g} / \mathrm{cm}^{2}$.

Proline determination: 'The proline content was determined according to Bates et al. (1973).

\section{Statistical analysis}

Each treatment was performed in six jars containing five explants and each experiment was replicated three times. Data were subjected to analysis of variance by MSTAT-C (1990) Computer statistical analysis program. LSD, test at the $5 \%$ level of significance $(\mathrm{P}=0.05)$ 


\section{Results and Discussions}

Effect of different concentrations of sodium chloride on morphological parameters

The phenotype and vegetative growth characteristics were affected with salinity stress treatments (Table 1). It was clear that increasing of salt concentration lead to decrease of number of survival callus (Fig.1). No calluses were survived at 5000ppm salt concentration. The same trend was showed with number of regenerated plantlets and number of survival plantlets. These results are in harmony with Yacoubi et al. (2010) who stated that with increasing salinity concentration $(0$ to $9 \mathrm{gm} / \mathrm{L} \mathrm{NaCl})$ in Troyer citrange, a gradual decrease in Callus growth was observed.
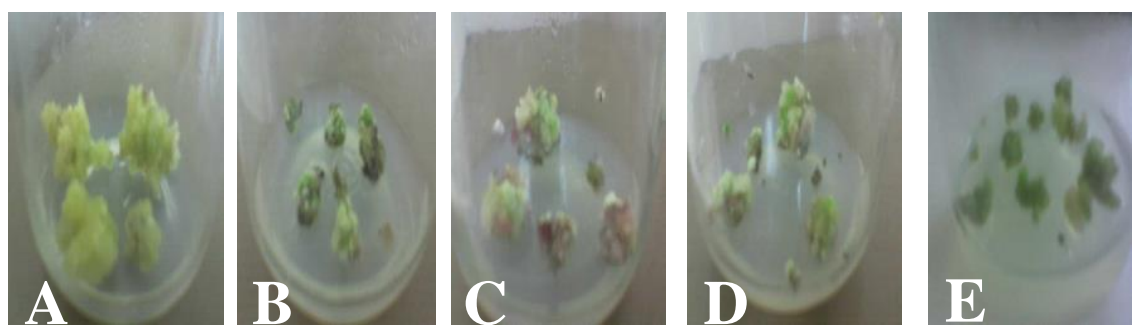

Fig. 1. Callus formation resulted from the control(A), $1000 \mathrm{mg} . \mathrm{L}^{-1}(B), 2000 \mathrm{mg} . \mathrm{L}^{-}$ ${ }^{1}(C), 3000 \mathrm{mg} . \mathrm{L}^{-1}(\mathrm{D})$ and $4000 \mathrm{mg} . \mathrm{L}^{-1}(\mathrm{E}) \mathrm{NaCl}$.

Retardant effect of salt concentrations (2000 mg.L $\mathrm{L}^{-1}, 3000 \mathrm{mg} . \mathrm{L}^{-1}$ and 4000 $\mathrm{mg} . \mathrm{L}^{-1}$ ) was observed on vegetative growth parameters (plantlet length, number of leaves, leaf area, number of roots and length of roots). The opposite was true for $1000 \mathrm{mg} . \mathrm{L}^{-1}$ of sodium chloride; morphological measurements of vegetative growth parameters were increased. This could be interpreted by $\mathrm{Na}^{+}, \mathrm{Cl}^{-}$or both together play a chemical role that may enhanced growth of pear plantlets at this concentration. In this respect, yacoubi et al. (2010) found that 57 out of 1400 explants cultured for a month of stress on $4 \mathrm{gm} / \mathrm{L}$ of sodium chloride showed fast growth and equivalent size to that of control.

TABLE 1. Effect of different concentrations of sodium chloride on callus Survival, regenerated plantlets and vegetative parameters of plantlets resulted from using different concentrations.

\begin{tabular}{|c|c|c|c|c|c|c|c|c|c|}
\hline 泀 & 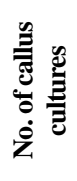 & 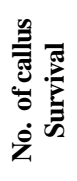 & 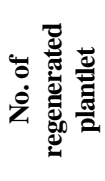 & 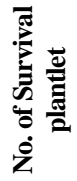 & 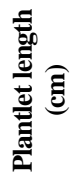 & 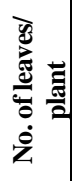 & 氖 & 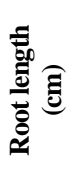 & $\begin{array}{l}\frac{0}{0} \\
\stackrel{0}{0} \\
\frac{\Xi}{0} \\
\dot{0} \\
\dot{z}\end{array}$ \\
\hline Control & 60 & 60 & 53.00 & 51.75 & 6.52 & 5.67 & 2.62 & 5.64 & 5.90 \\
\hline $1000 \mathrm{mg} \mathrm{L}^{-1}$ & 60 & 43.67 & 37.47 & 25.00 & 7.33 & 6.33 & 3.02 & 6.39 & 6.93 \\
\hline $2000 \mathrm{mg} \mathrm{L}^{-1}$ & 60 & 34.33 & 26.33 & 12.67 & 6.24 & 4.67 & 2.22 & 5.00 & 5.29 \\
\hline $3000 \mathrm{mg} \mathrm{L}^{-1}$ & 60 & 20.00 & 9.50 & 7.00 & 6.17 & 4.33 & 2.37 & 4.00 & 5.16 \\
\hline $4000 \mathrm{mg} \mathrm{L}^{-1}$ & 60 & 10.67 & 4.00 & 1.00 & 5.22 & 4.00 & 2.12 & 3.33 & 4.23 \\
\hline $5000 \mathrm{mg} \mathrm{L}^{-1}$ & 60 & - & $\longrightarrow$ & - & $\longrightarrow$ & - & - & - & - \\
\hline L.S.D at 0.5 & & 3.41 & 2.49 & 2.81 & 0.43 & 0.69 & 0.41 & 1.26 & 1.01 \\
\hline
\end{tabular}

Egypt. J. Hort. Vol. 40, No.1 (2013) 
Effect of different concentrations of sodium chloride on growth rate development

Increment of salt concentration reduced the fresh weight gradually from the $1000 \mathrm{mg} . \mathrm{L}^{-1}$ to $4000 \mathrm{mg} . \mathrm{L}^{-1}$ (Fig.2 \&Table 2). The growth rate of fresh weight decreased in $2000 \mathrm{mg} . \mathrm{L}^{-1}, 3000 \mathrm{mg} . \mathrm{L}^{-1}$, and $4000 \mathrm{mg} . \mathrm{L}^{-1}$ salt concentration in comparison with the control; meanwhile, it was increase by 1.28 times for $1000 \mathrm{ppm}$. Furthermore, the relative growth rate of fresh weight also decreased with all of the examined concentrations except for 1000ppm which folded by 1.1 in comparison with the control.
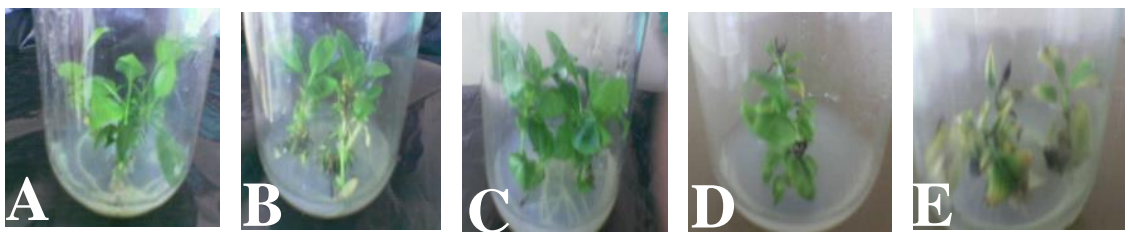

Fig. 2. Regenerated plantlet resulted from the control(A), $1000 \mathrm{mg} . \mathrm{L}^{-1}(B), 2000 \mathrm{mg} . \mathrm{L}^{-}$ $1(C), 3000$ mg. $\mathrm{L}^{-1}(\mathrm{D})$ and $4000 \mathrm{mg} . \mathrm{L}^{-1}(\mathrm{E}) \mathrm{NaCl}$.

Yacoubi et al. (2010) observed that, in Troyer citrange rootstock calli treated with $\mathrm{NaCl}$ at 4 and $6 \mathrm{gm} / \mathrm{L}$ were insufficient to cause a relative reduction of $50 \%$ compared to the control. However, more significant retarding effect was observed at 8 and $9 \mathrm{gm} / \mathrm{L} \mathrm{NaCl}$ concentration, and the relative growth rate of stressed calli strongly decreased by $65 \%$ and $75 \%$, respectively. On the other hand, Balal et al. (2011) demonstrated that, the fresh and dry weight was affected by $\mathrm{NaCl}$ treatments, with a greater reduction as $\mathrm{NaCl}$ concentration was increased in Citrus rootstocks.

TABLE 2. Growth rate development as affected by salinity stress.

\begin{tabular}{|c|c|c|c|c|}
\hline Treatments & $\begin{array}{c}\text { Initial fresh } \\
\text { weight (gm) }\end{array}$ & $\begin{array}{c}\text { Final fresh } \\
\text { weight }(\mathbf{g m})\end{array}$ & $\begin{array}{c}\text { Fresh growth } \\
\text { rate }\end{array}$ & $\begin{array}{c}\text { Relative growth } \\
\text { rate of fresh } \\
\text { growth }\end{array}$ \\
\hline Control & 9.37 & 20.37 & 1.17 & 100.00 \\
$1000 \mathrm{mg} / \mathrm{L}^{1}$ & 8.12 & 18.56 & 1.28 & 109.40 \\
$2000 \mathrm{mg} / \mathrm{L}^{1}$ & 7.60 & 13.34 & 0.76 & 64.95 \\
$3000 \mathrm{mg} / \mathrm{L}^{1}$ & 7.57 & 10.60 & 0.40 & 34.18 \\
$4000 \mathrm{mg} / \mathrm{L}^{1}$ & 5.14 & 6.67 & 0.29 & 24.79 \\
\hline
\end{tabular}

Effect of different salinity concentrations on some chemical constitutes

Accumulation of different solutes due to salt stress has been reported by many workers. The commonly reported solutes are proline and total cholorophyll; therefore, estimation of proline and total chlorophyll content were achieved in the present study. Concerning the prolin, as salinity concentration increase, the proline content increase. However, in $1000 \mathrm{mg} . \mathrm{L}^{-1}$ concentration the difference was not significant in compare with the control.

No significant difference was observed again with $3000 \mathrm{mg} . \mathrm{L}^{-1}$ and 4000 mg. $\mathrm{L}^{-1}$ concentrations. Furthermore, soudium chloride at $2000 \mathrm{mg} . \mathrm{L}^{-1}$ concentration recorded a significant differences within all of the tested 
concentrations (Fig. 3). It has been reported that proline content increase due to salinity stress in different plants (Ashraf \& Bashir, 2003). Inherited difference in the accumulation of proline in various geotypes of plants has also been reported and its osmolyte is more widely accumulated in higher plants, than other amino acids under salt stress conditions (Abraham et al., 2003). Moreover, accumulation of proline contributes towards membrane stability (Dondini et al., 2001).

Furthermore, total chlorophyll was decreased when salt concentration increased (Fig. 3). The difference was significant between the control and the tested concentrations of salinity $\left(1000 \mathrm{mg} . \mathrm{L}^{-1}, 2000 \mathrm{mg} . \mathrm{L}^{-1}, 3000 \mathrm{mg} . \mathrm{L}^{-1}\right.$ and $\left.4000 \mathrm{mg} . \mathrm{L}^{-1}\right)$. These results could be interpreted the shortage in plant fresh weight, decreasing in chlorophyll content will subsequently affect the accumulation of nutrients necessary for plant growth (Gu et al., 2004). However, another study (Evain et al., 2004) reported an increasing in chlorophyll contents in some cultivars of different plant species. In this respect, Balal et al. (2011) stated that, different workers gave different reasons for increasing or decreasing of chlorophyll contents. Salinity may be responsible for lower value of stomatal conductance, photosynthesis and relative water content. Meanwhile, another researchers summarized the reduction in chlorophyll may be due to variation in its synthesis between the plant species due to variation in enzymes under saline conditions (Balal et al., 2011).

Sodium and chloride content were much higher than the control especially with the $3000 \mathrm{mg} . \mathrm{L}^{-1}$ and $4000 \mathrm{p} \mathrm{mg. \textrm {L } ^ { - 1 }}$ concentrations (Fig. 4). Sodium and chloride accumulation were folded by 1.1 and 1.2 , respectively for $1000 \mathrm{mg} . \mathrm{L}^{-1}$ concentration. However, in the $3000 \mathrm{mg} . \mathrm{L}^{-1}$ concentration, the increments were 1.95 and 1.84 for both sodium and chloride, respectively. On the other hand, both sodium and chloride were twice highest at $2000 \mathrm{mg} . \mathrm{L}^{-1}$ concentration. These results are in harmony with Yacoubi et al. (2010).

It could be concluded that, the resistant plants resulted from this experiment might be subjected to a higher saline concentrations and grafted by some pear cultivars to examine it.

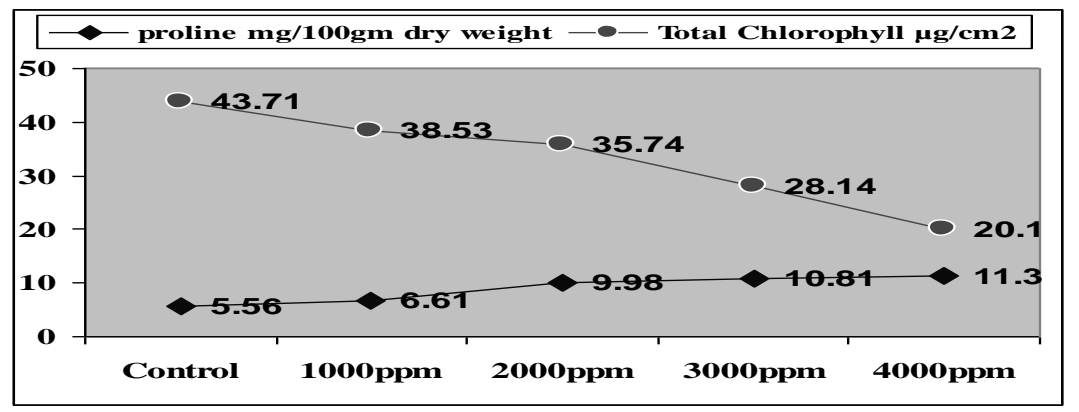

Fig. 3. Effect of different salinity concentrations on proline and total chlorophyll content.

Egypt. J. Hort. Vol. 40, No.1 (2013) 


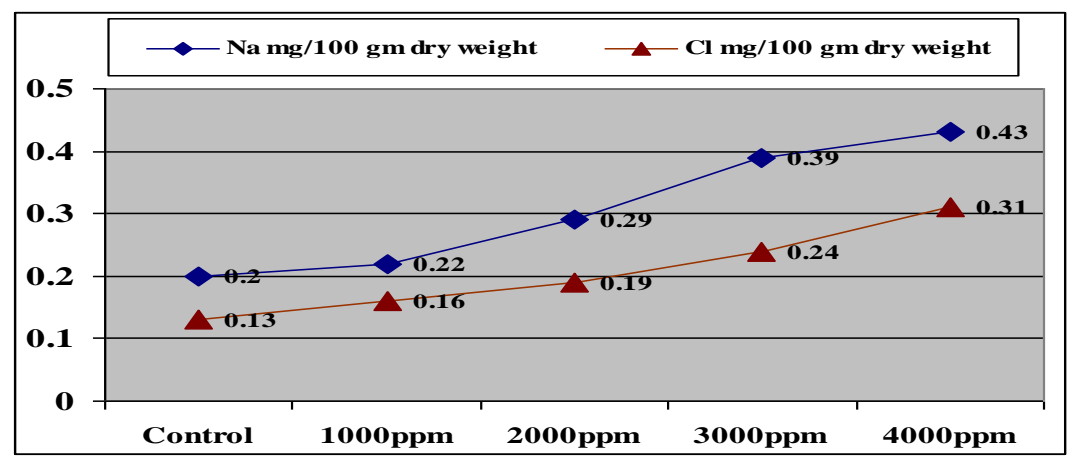

Fig. 4. Effect of different salinity concentrations on sodium and chloride content.

\section{References}

Abd El-Rahman, M., Al-Ansary, F., Aida, A.R. and Awatef, M.B. (2007) Micropropagation and biochemical genetic markers detection for drought and salt tolerance of pear rootstock. Australian Journal of Basic and Applied Sciences, 1(4), 625-636.

Abraham, E., Rigo, G., Szekely, G., Vagy, R., Konez, C. and Szabados, L. (2003). Light dependent induction of proline biosynthesis by abscisic acid and salt stress inherited by brassinosteroid in Arabidopsis, Plant Mol. Biol., 51, 363-372.

Al-Mansoori, T.A., Alaa Eldeen, M.N. and Caligari, P.D.S. (2007) Evaluation techniques for salt tolerance in date palm. Acta Horticulture, 736, 301-307.

Ashraf, M. and Bashir, A. (2003) Salt stress induced change in some organic metabolites and ionic relations in nodules and other plant parts of two crop legumes differing in salt tolerance. Flora, 198, 486- 498.

Balal, R.M., Ashraf, M.Y., Khan, M.M., Jaskani, M.J. and Ashfaq, M. (2011) Influence of salt stress on growth and biochemical parameters of Citrus rootstocks. Pak. J. Bot., 43, 2135-2141.

Bates, L.S., Waldron, R.P. and Teaxe, I.W. (1973) Rapid determination of free proline for water stress studies. Plant and soil, 39, 205-207.

Brown, J.D. and Lilleland, O. (1946) Rapid determination of potassium and sodium in plant material and soil extract by flame photometry. Proc. Amer. Soc. Hort. Sci., 48, $341-460$.

Chandler, S.F., Ragolsky, E.G. and Egrat, T.A. (1987) Some morphogenic effects of sodium sulphate on tobacco callus. Plant Cell Tissue and Organ Culture, 52, 177-181.

Chevreau, E., Leuliette, S. and Gallet, M. (1997) Inheritance and linkage of isozme loci in pear (Pyrus communis L.). Theo. Appl. Gen., 94, 498-506. 
Cuartero, J., Boları, M.C., Asi, M. J. and Moreno, V. (2006) Increasing salt tolerance in the tomato. Journal of Experimental Botany, 57 (5) ,1045-1058.

Dondini, L., Bonazzi, S., Del-Duca, A., Bregolia, M. and Serafni-Fracassini, D. (2001) Accumulation of chloroplast transglutaminase to high $\mathrm{NaCl}$ concentration in polyamine deficient variant strain in Dunaliella saline and in its wild type. J. Plant Physiol., 158,185-197.

Evain, S., Flexas, J. and Moya, I. (2004) A new instrument for passive remote sensing:2, Measurement of leaf and canopy reflectance change at $531 \mathrm{~nm}$ and their relationship with photosynthesis and chlorophyll fluorescence. Remote Sen. Envi., 91, 175- 185.

FAO (2002) Grops and Drops. Making the best use of water for agriculture Organization of the United Nations. Roma, 26 p.

Flowers, T.J. (2004) Improving crop salt tolerance. Journal of Experimental Botany, 55, 307-319.

Grandillo, S., Zamir, D. and Tanksley, S.D. (1999) Genetic improvement of processing tomatoes: a 20 years perspective. Euphytica, 110, 85-97.

Gu, R., Fonseaca, S., Puskas, L., Hackler, L., Zvara, A., Dudits, D. and Pais, M. (2004) Transcript identification and profiling during salt stress and recovery of Populus euphrana. Tree Physiol., 24, 265-276.

Higinbothan, N., Ethertor, B.U. and Foster, R. E. (1967) Mineral contents and cell transmembrane electro-potentials of pea oat seedling tissue. Plant physiology, 42, 37- 46.

Jackson, M.L. (1958) Soil chemical analysis. New Jersey Prentice- Hall Inc. Englewood, Cliffs, J.J. (Hort. Abst. 47, 10237).

MSTAT-C. (1990) Microcomputer statistical program for experiment design and analysis. MSTAT / Michigan State University, Michigan, USA.

Murashige, T. and Skoog, F. (1962) A revised medium for rapid growth and bioassays with tobacco tissue cultures. Physiol. Plant., 15, 473-497.

Sen, D.N. and Mohammed, S. (1994) Genetic aspects of salinity and biology of saline plants., In: M. Pessarakli (Ed.), pp: 125-145, Handbook of Plant and Crop Stress. Marcel Dekker Inc., New York.

Sengupta, S. and Majumder A.L. (2009) Insight into the salt tolerance factors of a wild holophytic rice. Porteresia coarclata :a physiological and proteomic approach. Planta, 229, 911-929

Yacoubi, H., Koutoua, A. and Rochdi, A. (2010) In vitro cellular salt tolerance of Troyer citrange: Changes in growth and solutes accumulation in callus tissue. Int. $J$. Agric. Biol., 12,187-193. 
INDUCTION SOMACLONAL VARIATION IN PEAR PLANTS ...

استحداث اختلافات فى نبات الكمثرى للمقاومة للملوحة من خلال

زراعة الانسجة أنتات

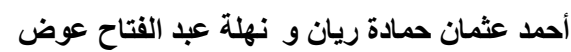

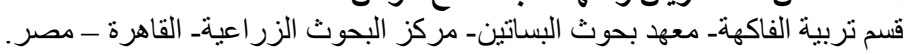

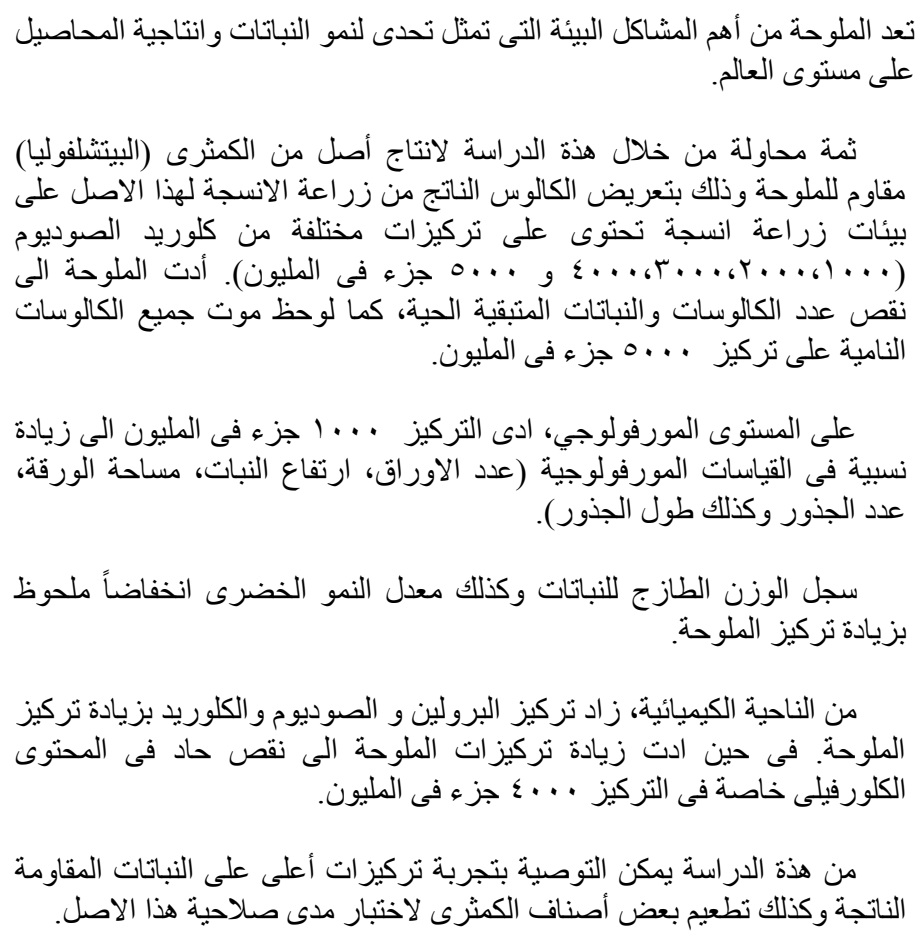

